\title{
Экономические аспекты развития микроэлектроники КНР
}

УДК 621.38 | ВАК 05.13 .01

\author{
М. Макушин ${ }^{1}$, А. Фомина, д. э. н. ${ }^{2}$
}

В последние годы микроэлектроника КНР демонстрирует отличные количественные и качественные темпы роста. Дальнейшее ее развитие связано с более глубоким встраиванием в национальную экономику, использованием новых подходов и технологий, включая искусственный интеллект. Пока же КНР сильно зависит от импорта ИС, который по стоимости превосходит закупаемую нефть. Руководством страны поставлена задача увеличения внутреннего производства ИС в целях снижения зависимости от импортной продукции. Удастся ли достичь целей в условиях торговой войны с США и ограничений на доступ к высоким технологиям, вводимых странами-конкурентами?

\section{ОБЩАЯ СИТУАЦИЯ В МИРОВОЙ МИКРОЭЛЕКТРОНИКЕ}

Ситуация в мировой микроэлектронике складывается во многом под воздействием неопределенности перспектив развития противоречий США с КНР и Европой (вКлючая проблему Брексита). По оценкам исследовательской корпорации IC Insights (Скоттсдэйл, шт. Аризона), в текущем году доходы от продаж полупроводниковых приборов увеличатся на 1,6\%, а в следующем - сократятся на 0,9\%. Затем, по прогнозам, на протяжении трех лет рост будет составлять от 7 до 13\% (рис. 1). Причем темпы увеличения продаж ИС китайских фирм в целом будут значительно опережать общемировые показатели. Одна из тенденций на мировом рынке - конец двухлетнего "суперцикла" роста продаж схем памяти, прежде всего ДОЗУ. Не исключается, что средние продажные цены ИС к концу года снизятся на 6\%.

После введения 25\%-ных ставок таможенного тарифа на импортируемую китайскую микроэлектронику американские аналитики отмечают, что у Китая и США есть "много стимулов" для урегулирования торговой войны. Попытки провести в Конгрессе запрет продаж ИС компаний Huawei и ZTE, а также другие антикитайские ограничения встречают активное сопротивление Ассоциации полупроводниковой промышленности США. Причина в КНР расположено много производственных филиалов американских фирм, и подобные меры приведут к удорожанию конечных электронных систем, изготавливаемых в США, и снижению их конкурентоспособности на мировом рынке [1]. Структура мирового рынка ИС по типам изделий представлена в табл. 1.

АО «ЦНИИ «Электроника», главный специалист,

mmackushin@gmail.com.

АО «ЦНИИ «Электроника», генеральный директор.

\section{СОВРЕМЕННОЕ СОСТОЯНИЕ КИТАЙСКОЙ МИКРОЭЛЕКТРОНИКИ}

В результате реализации Рекомендаций по развитию национальной полупроводниковой промышленности (促进国家集成电路产业发展的指导方针), опубликованных Госсоветом КНР в июне 2014 года и разработанных в целях формулирования основных руководящих принципов политики и инвестиционной поддержки микроэлектроники КНР, а также плана “Сделано в Китае - 2025» (中国制造2025) полупроводниковая промышленность этой страны демонстрирует быстрый рост, который, как ожидается, станет одним из драйверов мировой полупроводниковой промышленности. В области проектирования ИС китайские fabless-фирмы, такие как HiSilicon и Unigroup Spreadtrum \& RDA, вошли в первую десятку крупнейших в мире разработчиков ИС. В области обработки пластин на китайские производственные мощности по изготовлению ИС приходится 13-15\% мировых производственных мощностей (правда, продажи собственно китайских фирм почти в два раза меньше, поскольку площадки китайских кремниевых заводов используются во многом для контрактного производства зарубежных фирм и продукция учитывается как выпущенная этими фирмами). И это несмотря на то, что крупнейшие китайские производители ИC - SMIC и Huahong Group - отстают от зарубежных конкурентов в освоении новейших производственных процессов. В области проектирования ИС китайские fablessфирмы, такие как HiSilicon и Unigroup Spreadtrum \& RDA, вошли в первую десятку крупнейших в мире разработчиков ИС. В области корпусирования и тестирования ИС китайские фирмы (JCET, NFME и Huatian Technology) также входят в первую десятку фирм мира.

"Рекомендации..." и "План..." привели к буму капиталовложений. Однако для обеспечения новых 


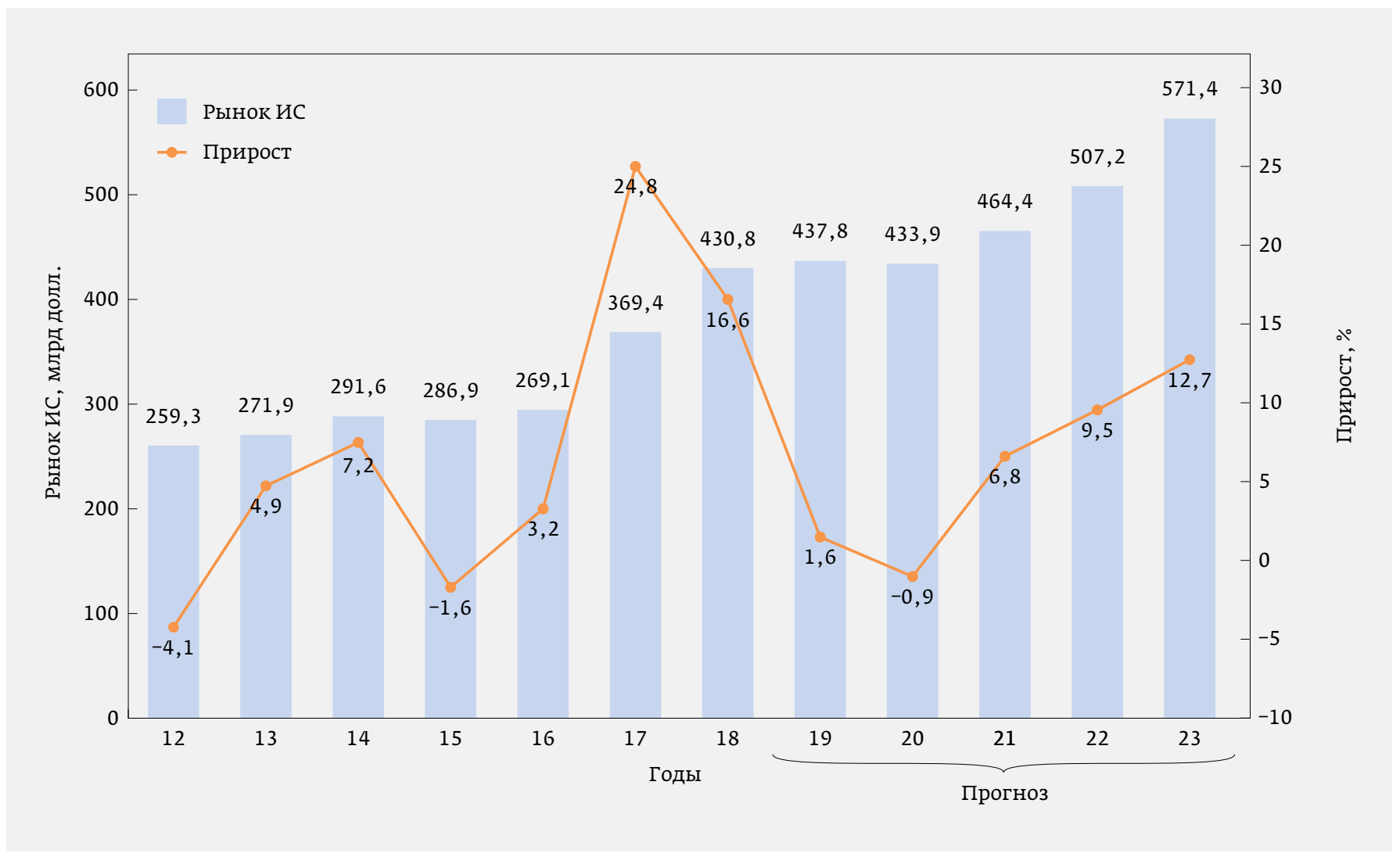

Рис. 1. Динамика мирового рынка полупроводниковых приборов (до 2018 года фактически, далее прогноз). Источник: IC Insights

возможностей развития и процветания китайской микроэлектроники инвестиции должны выйти далеко за рамки сооружения заводов по обработке пластин. Стратегия устойчивого и долгосрочного роста национальной полупроводниковой промышленности при дальнейших существенных капиталовложениях должна уделять больше внимания инновационным технологиям. Хотя реализация инновационного подхода требует времени, она приведет к увеличению спроса на производственные мощности, росту ВВП и числа рабочих мест [2].

В соответствии с «Рекомендациями..." в 2014 году был создан Фонд развития микроэлектроники Китая (China IC Fund), который за прошедшие годы привлек на цели развития перспективных технологий микроэлектроники и изделий микроэлектроники порядка 22 млрд долл. Помимо этого в ряде провинций и крупных городов было создано 11 местных фондов развития микроэлектроники. В целом, предпринимаемые в последние годы усилия по развитию национальной полупроводниковой промышленности призваны если не устранить, то существенно ослабить зависимость осуществляемого в КНР производства электронных систем от закупки зарубежных ИС и полупроводниковых приборов.
Ежегодный объем импорта превышает 100 млрд долл. На преодоление этой зависимости за счет развития национальной микроэлектроники предполагается направить в течение десяти лет порядка 161 млрд долл. Из них 63-65 млрд долл. придется на центральный фонд, остальное - на местные фонды и частных инвесторов.

Однако государственное финансирование полупроводниковой промышленности КНР превратилось в один из очагов напряженности во взаимоотношениях с США, 
Таблица 1. Структура мирового рынка ИС в 2016-2019 годах. Источник: IC Insights

\begin{tabular}{|c|c|c|c|c|c|c|c|c|}
\hline \multirow{2}{*}{ Период } & \multicolumn{2}{|c|}{ Аналоговые ИС } & \multicolumn{2}{|c|}{ Логика* } & \multicolumn{2}{|c|}{ Память } & \multicolumn{2}{|c|}{ Рынок ИС, всего } \\
\hline & Всего & Прирост, \% & Всего & Прирост, \% & Всего & Прирост, \% & Всего & Прирост, \% \\
\hline 2016 & & & & & & & & \\
\hline Продажи, млрд долл. & 49,44 & 5 & 167,23 & 4 & 79,44 & 2 & 296,10 & 4 \\
\hline Отгрузки, млрд шт. & 133,26 & 6 & 75,73 & 6 & 42,68 & 12 & 251,67 & 7 \\
\hline СПЦ, долл. & 0,37 & -1 & 2,21 & -1 & 1,86 & -9 & 1,18 & -3 \\
\hline
\end{tabular}

\section{7}

\begin{tabular}{lrrrrrrr}
\hline Продажи, млрд долл. & 54,54 & 10 & 184,92 & 11 & 129,92 & 64 & 369,38 \\
Отгрузки, млрд шт. & 154,84 & 16 & 90,16 & 19 & 44,61 & 5 & 289,61 \\
СПЦ, долл. & 0,35 & -5 & 2,05 & -7 & 2,91 & 56 & 1,28 \\
\hline
\end{tabular}

\section{8}

\begin{tabular}{lrrrrrrr}
\hline Продажи, млрд долл. & 60,26 & 10 & 202,09 & 9 & 168,45 & 30 & 430,80 \\
Отгрузки, млрд шт. & 177,35 & 15 & 100,50 & 11 & 43,53 & -2 & 321,38 \\
СПЦ, долл. & 0,34 & -4 & 2,01 & -2 & 3,87 & 33 & 1,34 \\
\hline
\end{tabular}

\section{9 (прогноз)}

\begin{tabular}{lrrrrrrrr}
\hline Продажи, млрд долл. & 64,86 & 8 & 215,00 & 6 & 157,95 & -6 & 437,81 & 2 \\
Отгрузки, млрд шт. & 193,18 & 9 & 110,29 & 10 & 43,75 & 1 & 347,23 & 8 \\
СПц, долл. & 0,34 & -1 & 1,95 & -3 & 3,61 & -7 & 1,26 & -6 \\
\hline
\end{tabular}

Включая логику и микрокомпоненты (микропроцессоры, микроконтроллеры, микропериферия, цОС-процессоры).

которая вылилась в торговую войну. США утверждают, что поддержка китайским правительством национальной микроэлектроники - антиконкурентная практика.

Обострение торговых противоречий с США, а также странами ЕС, Тайванем и Японией может привести к ограничению доступа КНР на эти рынки и к передовым технологиям. Соответственно, требуется увеличить финансирование внутренних НИОКР. По данным Wall Street Journal, правительство КНР намеревалось создать в конце 2018-го - начале 2019 года второй центральный инвестиционный фонд развития микроэлектроники - China Integrated Circuit Industry Investment Fund, ориентированный в первую очередь на стимулирование НИОКР по перспективным направлениям. Первоначально предполагалось, что объем средств фонда составит от 19 до 32 млрд долл. Теперь же из-за американо-китайских торговых противоречий сумма может быть увеличена. Средства нового фонда, выделяемые на развитие полупроводниковых и смежных технологий, в частности, предназначены для расширения возможностей китайских фирм в области проектирования

$\begin{array}{llc}\begin{array}{l}\text { Установленные } \\ \text { мощности, } \\ \text { млн пластин/месяц }\end{array} & \begin{array}{r}\text { Доля в мировом парке } \\ \text { установленного } \\ \text { оборудования, \% }\end{array} \\ 4,126 & \text { Тайвань } & 21,8 \\ 4,033 & \text { Южная Корея } & 21,3 \\ 3,168 & \text { Япония } & 16,8 \\ 2,426 & \text { Северная Америка } & 12,8 \\ 2,361 & \text { КнР } & 12,5 \\ 1,138 & \text { Европа } & 6,0 \\ 1,646 & \text { Прочие страны } & 8,7 \\ 18,897 & \text { Всего } & 100\end{array}$

Рис. 2. Географическое распределение установленных производственных мощностей по обработке пластин по состоянию на декабрь 2018 года (месячная производственная мощность в пересчете на эквивалент 200-мм пластин). Источник: IC Insights 
и производства перспективных центральных и графических процессоров [3].

\section{МЕСТО КНР В МИРОВОМ ПАРКЕ УСТАНОВЛЕННОГО ОБОРУДОВАНИЯ}

Благодаря амбициозным планам развития внутренней полупроводниковой промышленности КНР по итогам 2018 года она продемонстрировала самые высокие темпы прироста парка установленного оборудования ее доля в мировом парке такого оборудования достигла 12,5\% (рис. 2) по сравнению с 10,8\% в 2017-м. По этому показателю Китай почти догнал Северную Америку. (Учитываются мощности китайских и зарубежных фирм, производственные подразделения которых находятся на территории Поднебесной).

Лидером по мощности установленного оборудования с 2015 года остается Тайвань [4].

\section{ОТ СООРУЖЕНИЯ К ОСНАЩЕНИЮ ЗАВОДОВ}

В соответствии с пятилетним планом, КНР переходит от этапа сооружения заводов по обработке пластин к их оснащению оборудованием. Бум строительства таких предприятий пришелся на 2017 год, когда в Китае начали возводить 26 производств по обработке пластин различного диаметра для

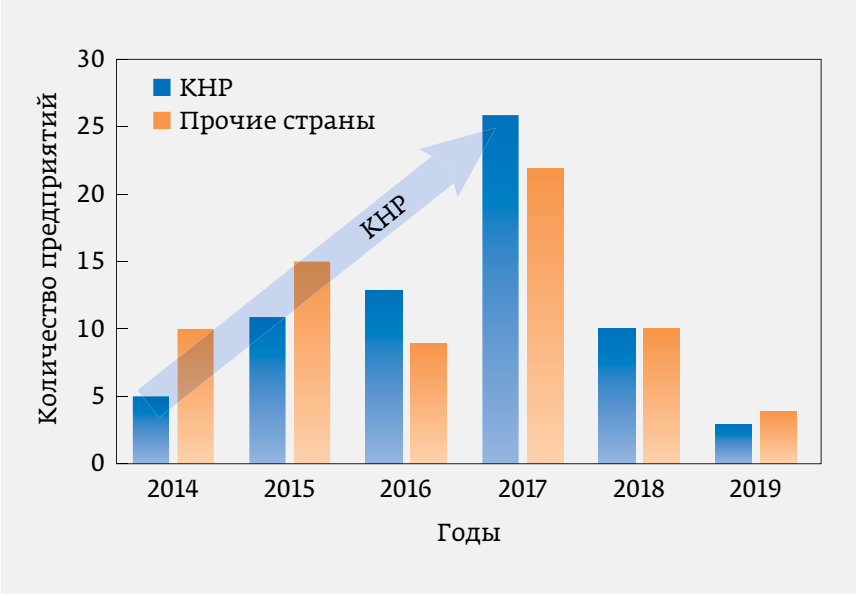

Рис. 3. Количество вводимых в строй предприятий (все заявленное с учетом производства дискретных полупроводниковых приборов). Источник: World Fab Forecast report, Feb. 28, 2018, SEMI

формирования ИС и дискретных полупроводниковых приборов (рис. 3).

До 2016-2018 годов наибольшие затраты на полупроводниковое оборудование в КНР несли иностранные фирмы. Однако ситуация постепенно меняется: доля 
расходов на эти цели местных фирм может увеличиться с 33\% в 2017 году до 45\% в 2019-м.

Крупнейшим по инвестициям в оборудование сектором остаются 3D-схемы флеш-памяти NAND-типа (16 млрд долл. в 2018 году и 17 млрд долл. в 2019-м) Инвестиции в сектор ДОЗУ в 2018 году увеличились на 26\% (до 14 млрд долл.), но в 2019-м сократятся на 14\% (до 12 млрд долл.). Капиталовложения в сектор кремниевых заводов в 2018 году выросли на 2\% - до 17 млрд долл., в первую очередь в целях освоения производственных технологий с топологическими нормами 7 нм. В 2019 году ожидается их увеличение до 22 млрд долл. (рост на 26\%) [5].

\section{СОСТОЯНИЕ ВНУТРЕННЕГО ПРОИЗВОДСТВА МИКРОЭЛЕКТРОНИКИ В КНР}

В 2018 году основной объем производства ИС в КНР пришелся на расположенные в стране филиалы иностранных корпораций, включая Samsung, Intel, GlobalFoundries, SK Hynix и TSMC. Однако в ближайшие пять лет их серьезно потеснят быстро наращивающие мощности китайские производители, в частности SMIC, Huahong Group, YMTC и Changxin Memory Technologies. По прогнозам IC Insights, в 2023 году на эти и другие китайские фирмы придется более половины производства ИС в KНP (табл. 2) [6].

Таблица 2. Производственные мощности основных китайских фирм и филиалов иностранных корпораций, расположенных на территории КНР. Источник: база данных Strategic Review корпорации IC Insights, CCID, CSIA, PwC

\begin{tabular}{|c|c|c|c|c|c|c|}
\hline \multirow{2}{*}{$\begin{array}{l}\text { Место } \\
\text { в рейтинге } \\
\text { в } 2018\end{array}$} & \multirow[t]{2}{*}{ Фирма } & \multicolumn{4}{|c|}{ Объем продаж, млрд долл. } & \multirow[t]{2}{*}{ Деятельность } \\
\hline & & 2013 & 2017 & 2018 & 2023 & \\
\hline 1 & SK Hynix ${ }^{*}$ & 3,200 & 6,480 & 9,075 & 12,500 & дозу \\
\hline 2 & Samsung* & 0 & 3,800 & 4,560 & 6,300 & 3D NAND-флеш \\
\hline 3 & SMIC $^{* *}$ & 1,962 & 3,101 & 3,195 & 4,900 & Услуги кремниевого завода \\
\hline 4 & Intel $^{*}$ & 2,650 & 2,325 & 2,675 & 3,800 & 3D NAND-флеш \\
\hline 5 & Huahong Group ${ }^{* *}$ & 0,795 & 1,395 & 1,542 & 2,500 & Услуги кремниевого завода \\
\hline 6 & $\mathrm{TSMC}^{*}$ & 0,510 & 0,700 & 0,950 & 1,800 & Услуги кремниевого завода \\
\hline 7 & $\mathrm{XMC} / \mathrm{YMTC}$ & 0,150 & 0,250 & 0,300 & 5,400 & Услуги кремниевого завода/3D NAND \\
\hline 8 & CR Micro & 0,165 & 0,220 & 0,245 & 0,365 & $\begin{array}{l}\text { Услуги кремниевого завода / } \\
\text { стандартные ИС }\end{array}$ \\
\hline 9 & Diodes-BCD & 0,155 & 0,220 & 0,240 & 0,360 & $\begin{array}{l}\text { Услуги кремниевого завода / } \\
\text { стандартные ИС }\end{array}$ \\
\hline 10 & ASMC & 0,117 & 0,150 & 0,180 & 0,280 & Услуги кремниевого завода \\
\hline Прочие & & 0,575 & 0,690 & 0,810 & 8,800 & - \\
\hline \multicolumn{2}{|c|}{ Производство ИС в КНР, всего } & 10,279 & 19,331 & 23,772 & 47,005 & - \\
\hline \multicolumn{2}{|c|}{ Мировой рынок ИС } & 271,9 & 369,4 & 430,8 & 571,4 & - \\
\hline $\begin{array}{l}\text { Доля китай } \\
\text { вом рынке I }\end{array}$ & х фирм на миро- & 3,78 & 5,23 & 5,52 & 8,23 & - \\
\hline
\end{tabular}

Производство только китайских филиалов.

Включая Huahong Grace и Shanghai Huali. 


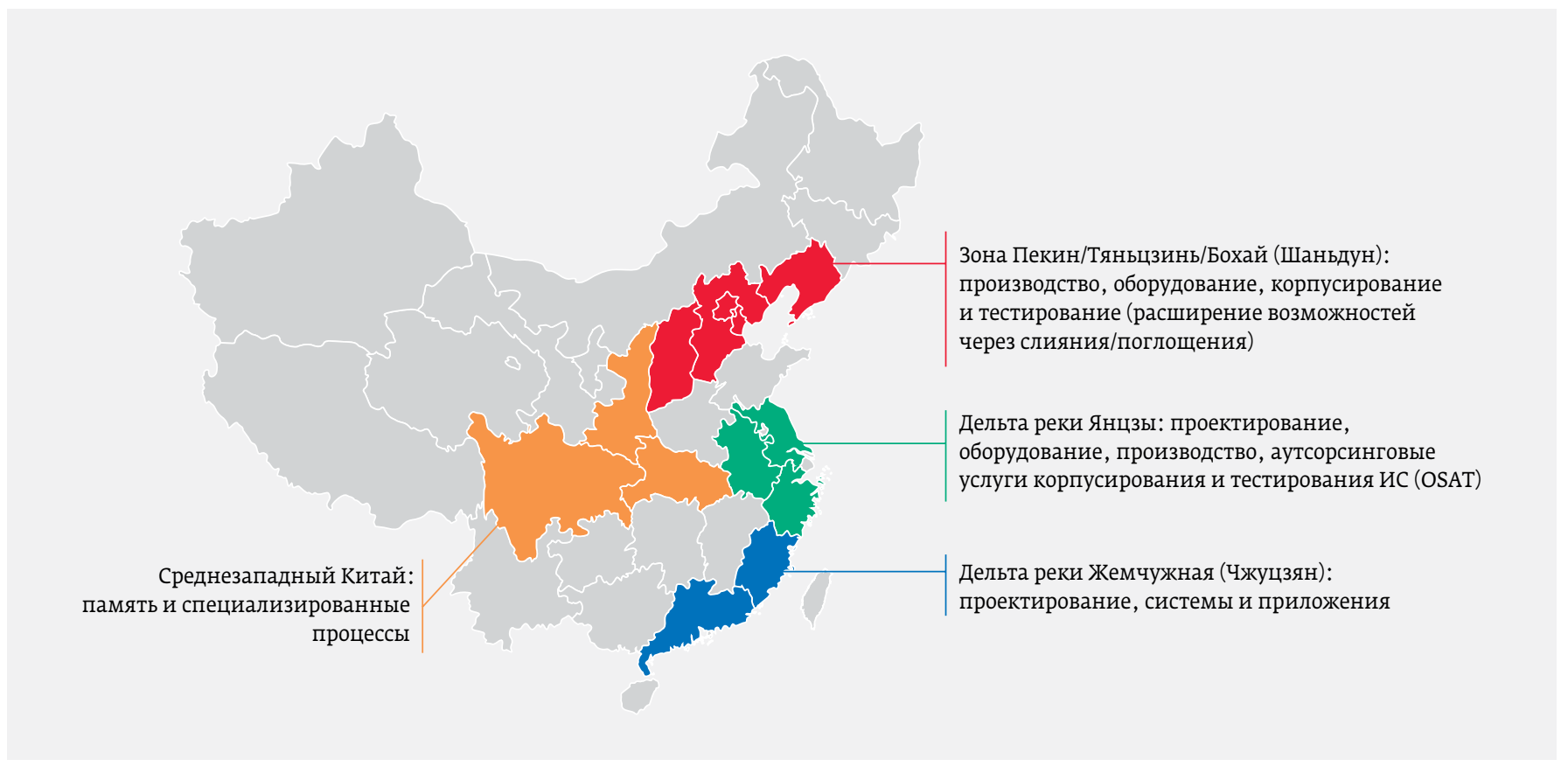

Рис. 4. Специализация основных центров микроэлектроники КНР. Источник: http://prod7.semi.org/en/sites/semi.org/files/datal7/ images/China_District_Regional_Map_600px.png

Завод по обработке 300-мм пластин южнокорейской корпорации SK Hynіх, расположенный в КHP, на конец 2018 года располагал наибольшим парком установленного оборудования среди всех предприятий корпорации. Месячная мощность его производства по обработке пластин при полной загрузке составляет 200 тыс. шт.

Корпорация Intel в III квартале 2015 года остановила свой завод по обработке 300-мм пластин в Даляне (Fab 68, с конца 2010 года производила микроконтроллеры) в связи с переходом к изготовлению 3D-схем флеш-памяти NAND-типа. Перевод завершился во II квартале 2016 года. Теперь установленные мощности составляют 70 тыс. пластин диаметром 300 мм в месяц (при полной загрузке).

В начале 2012 года корпорация Samsung получила разрешение южнокорейского правительства на строительство в Сиане завода по производству флеш-памяти NAND-типа на пластинах диаметром 300 мм. Производство запустили во II квартале 2014 года (к строительству приступили в сентябре 2012-го). Стоимость первого этапа проекта составила 2,3 млрд долл. при общем объеме инвестиций в проект порядка 7,0 млрд долл. На стадии освоения изготовления 3D-схем флеш-памяти NANDтипа (с 2017 года) вся продукция предназначалась исключительно для Samsung. В декабре 2018 года установленные мощности составили 100 тыс. (объявлено о планах довести этот показатель до 200 тыс. пластин в месяц) [4].
Кроме того, по сведениям IC Insights, в КНР расположены производства крупнейших электронных корпораций, которые также создают предприятия по производству ИС для нужд своих китайских филиалов. Так, например, корпорация Foxconn (Тайвань) заявила о намерении построить в Поднебесной завод по производству ТВ-чипсетов и формирователей сигналов изображения за 9 млрд долл. Это предприятие также будет оказывать услуги кремниевого завода [6].

Основными китайскими производителями ИС являются известные кремниевые заводы SMIC, Huahong Group, которых по мощностям быстро догоняют фирмы YMTC и ChangXin Memory Technologies, специализирующиеся на схемах памяти. В настоящее время в КНР ведется или планируется сооружение (на средства центрального правительства и местных провинций) 25 новых заводов / линий по обработке пластин, 17 из них предназначены для обработки пластин диаметром 300 мм. Основной специализацией новых предприятий будет оказание услуг кремниевого завода, производство дОзУ и 3D флеш-памяти NAND-типа.

Китайский сегмент корпусирования и тестирования ИС также уверенно развивается. Ценность предложений наращивается за счет сделок слияний/поглощений, а также создания расширенных возможностей для привлечения зарубежных производителей интегральных приборов.

Китайский рынок микроэлектронных материалов, на котором доминируют материалы для корпусирования 


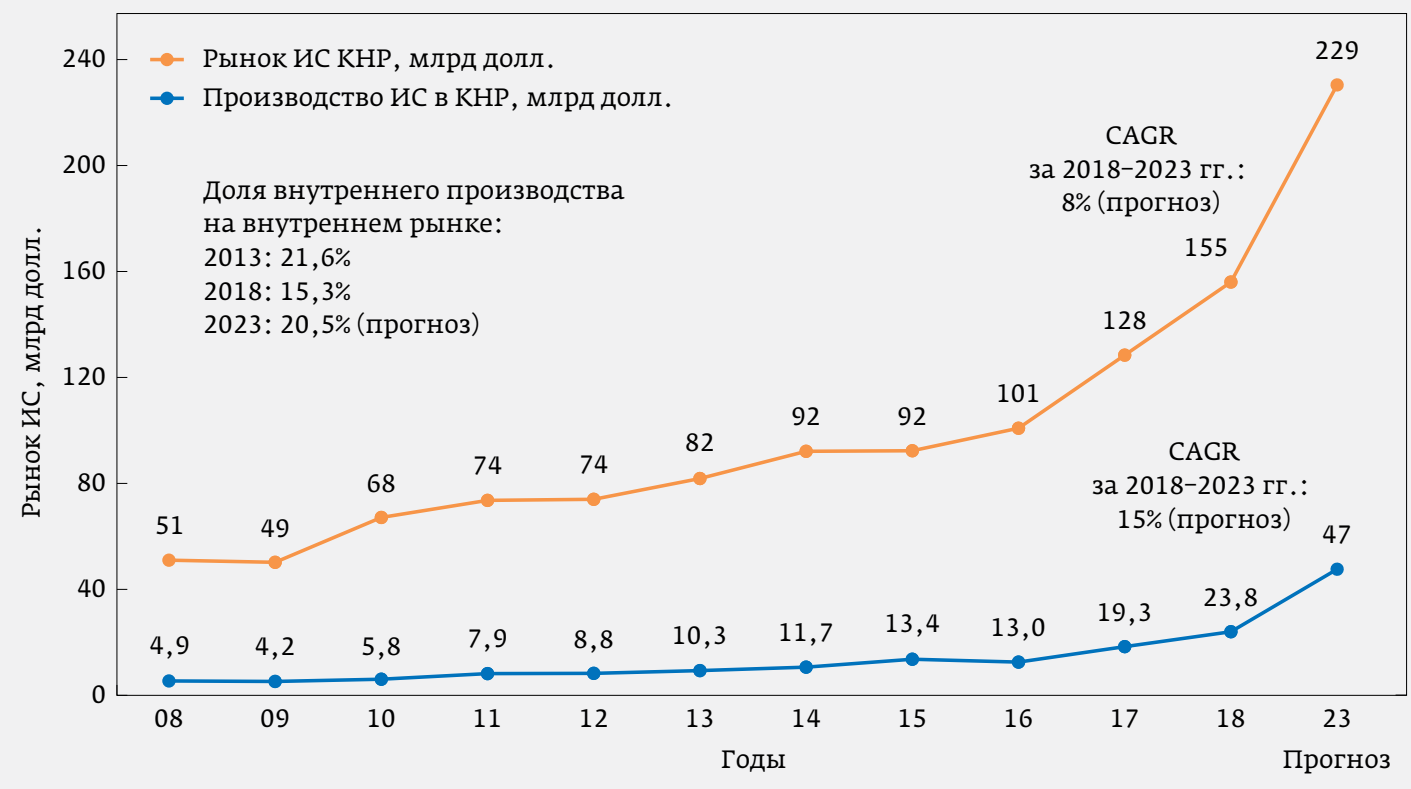

Рис. 5.

Сравнение

динамики

внутренних

рынка

и производства

ИС в КНР

за 2008-2023

годы.

Источник:

IC Insights

ИС, в 2016 году стал вторым по величине региональным рынком, а с 2017 года укрепляет позиции, сохраняя перспективу выйти на первое место в 2019-2020 годах. Как ожидается, рынок полупроводниковых материалов в этой стране за 2015-2019 годы должен продемонстрировать CAGR (сложные проценты) порядка 10\%, что обеспечивается в основном благодаря наращиванию мощностей заводов по обработке пластин. За этот же период CAGR увеличения объема производственных мощностей заводов по обработке пластин должен составить $14 \%$.

К настоящему времени на территории КНР сформировалось четыре крупных научно-промышленных комплекса, ориентированных на развитие микроэлектроники (рис. 4) и смежных отраслей. С ними активно работают Академия наук КНР (123 института) и ведущие университеты [7]

Как уже отмечалось, развитием микроэлектроники занимается не только центральное, но и местные правительства. Так, власти провинции Гуанчжоу начиная с 2015 года активно привлекают инвестиции зарубежных электронных фирм, включая Foxconn (Тайвань) и LG (Ю. Корея). Они также реализуют проект CanSemi (иногда называется Guangzhou Yuexin или ҮРС), в рамках которого в начале 2019 года предполагается ввести в строй завод по производству ИС для Интернета вещей, автомобильных сетей (внутриавтомобильные сети и транспортная инфраструктура), средств искусственного интеллекта и средств связи / сетей 5-го поколения (5G). Первоначально продукция будет выпускаться по топологиям от 40 до 28 нм.
До представления проекта CanSemi в начале 2018 года в рамках деятельности провинциального инвестиционного фонда развития микроэлектроники было заключено 15 сделок с фирмами в сфере проектирования, производства и тестирования ИС. Один из участников этих сделоккорпорация Guangdong Gowin Semiconductor, специализирующаяся на вентильных матрицах, программируемых пользователем. В 2017 году было 24 объявления об инвестициях в электронную промышленность Гуанчжоу, сделанных, в частности, корпорациями Cisco, General Electric (oбе США), Huawei, Tencent и ZTE (все KHP) [8]

\section{РЕАЛИСТИЧНОСТЬ ПЛАНОВ ПОД ВОПРОСОМ?}

По данным IC Insights, производство ИС в КНР за 2018-2023 годы почти удвоится - с 23,8 до 47 млрд долл. Соответственно, рост в сложных процентах (CAGR) за прогнозируемый период составит 15\%.

С 2005 года КНР - крупнейший в мире потребитель ИС. При этом доля внутреннего производства, по итогам 2018 года, составила 15,3\% объема внутреннего рынка ИС (155 млрд долл.) по сравнению с 12,6\% в 2013-м. К 2023 году этот показатель увеличится до 20,5\%. Однако разрыв в абсолютных показателях между объемом продаж и внутренним производством увеличится со 131,2 млрд долл. в 2018 году до 182 млрд долл. в 2023-м (рис. 5). При этом производство ИС в КНР в 2023 году составит всего 8,2\% прогнозируемого объема мирового рынка ИС в 571,4 млрд долл. [7].

Оценивая реальность достижения поставленных целей, специалисты IC Insights указывают на значительный прирост продаж ИС, которого могут добиться китайские 
фирмы в течение ближайших пяти лет. В первую очередь перечисляются крупнейший местный «чистый» кремниевый завод SMIC, Huahong Group, новые производители памяти YMTC и ChangXin Memory Technologies (CXMT, ранее Innotron). При этом стартап JНІСС (производство дозу) в настоящее время находится под американскими санкциями.

С учетом заявленных инвестиционных планов КНР на пять лет очевидно, что определенных успехов в снижении зависимости от импорта ИС КНР добьется. Однако все более пристальное внимание властей стран-конкурентов (в первую очередь США) к китайским попыткам приобретения высокотехнологичных фирм, а также правовые проблемы (включая судебные иски), с которыми китайские фирмы с большой вероятностью столкнутся в будущем, позволяют IC Insights предположить, что, несмотря на определенные успехи, заложенные планом "Сделано в Китае - 2025», показатели (самообеспеченность ИС на уровне 40\% в 2020 году и 70\% - в 2025-м) достигнуты не будут. Насколько близко китайцам удастся подойти к реализации целей, покажет время [4].

Однако у КНР есть возможность ускорить развитие национальной электроники за счет искусственного интеллекта.

\section{ИСКУССТВЕННЫЙ ИНТЕЛЛЕКТ - КЛЮЧ К ПРОРЫВУ?}

В июле 2017 года в рамках реализации XIII пятилетнего плана социально-экономического развития (2016-2020 гг.) ЦК КПК и Государственный Совет КНР утвердили План развития искусственного интеллекта следующего поколения (新一代人工智能发展规划), предусматривающий достижение поставленных в нем целей в три этапа с контрольными точками в 2020, 2025 и 2030 годах соответственно. К 2020 году предполагается довести уровень разработок искусственного интеллекта (ИИ) в КНР до уровня мировых стандартов и добиться значительных достижений в области приложений и теории ИИ. Использование ИИ в основных областях его применения должно принести прибыль не менее 150 млрд юаней. К 2025 году планируется принять основные законы и нормы регулирования сферы ИИ. Доход от использования технологии должен составить, по крайней мере, 400 млрд юаней, в том числе в таких секторах, как интеллектуальное производство, медицина, сельское хозяйство и градостроительное проектирование / городское планирование. Наконец, в 2030 году Китай должен стать ведущим разработчиком ИИ в мире, эта технология должна быть глубоко встроена в повседневную жизнь страны, а доход от ее применения - превысить 1 трлн юаней [9].

К основным задачам Плана относятся ускорение разработки интеллектуальной продукции, совершенствование прорывных технологий и углубление развития интеллектуальных производств. Первая задача подразумевает разработку интеллектуальных транспортных средств и сетей, обслуживающих роботов, БПЛА, медицинских диагностических систем формирования изображения, систем распознавания видеоизображений, интерактивных голосовых систем, систем перевода, а также изделий для интеллектуальных домов. Вторая - разработку интеллектуальных датчиков различного назначения, ИС нейронных сетей и платформ разработки с открытыми исходниками. Решение третьей задачи охватывает вопросы интеллектуального производства оборудования и различной продукции с использованием основных прорывных технологий, а также создание новых моделей интеллектуального производства.

Еще несколько целей Плана имеют отношение не к развитию, а к использованию изделий микроэлектроники [10]

В структуру Плана включено шесть глав: анализ стратегической ситуации, общие требования, специализированные задачи, распределение ресурсов, обеспечительные меры, их организация и осуществление. Общие требования описывают идеологию документа, базовые принципы, стратегические задачи, общие направления реализации. Специализированные задачи включают в себя создание открытых и координируемых научно-технических систем стимулирования инноваций в области ИИ, создание основных технологических систем ИИ следующего поколения, ускорение обучения и накопления талантов в области ИИ. К обеспечительным мерам относятся разработка соответствующего законодательства и мер регулирования, разработка стандартов и интеллектуальной собственности (в том числе защита прав интеллектуальной собственности) [11].

\section{АМЕРИКАНЦЫ ПУСКАЮТСЯ В ПОГОНЮ...}

В середине февраля текущего года президент США Д.Трамп распорядился сформировать скоординированную федеральную стратегию, призванную расширить американское лидерство в области исследований

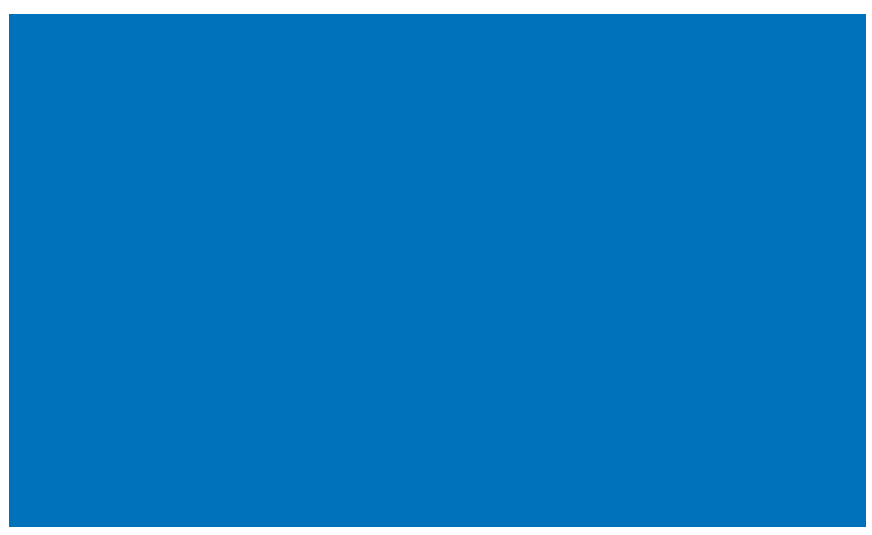


и развертывания ИИ, включая развитие технологий, создание стандартов и образовательных программ. Таким образом, НИОКР в области ИИ названы одним из высших приоритетов научно-технической политики страны.

Ассоциация полупроводниковой промышленности США (SIA) подчеркивает, что лидерство в области ИИ во многом основано на результатах НИОКР в области развития микроэлектронных технологий. Ежегодно на эти цели расходуются десятки миллиардов долларов - в 2017 году их сумма составила 36 млрд долл. По оценкам SIA, использование ИИ может привести кдополнительному наращиванию ВВП США на 8 трлн долл. в 2035 году, а годовой рост экономики увеличится с 2,6 до 4,6\%. При этом SIA опасается успешной реализации планов КНР в области развития ИИ [12].

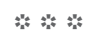

Итак, реально ли достижение КНР поставленных целей? Объем инвестиций, темпы строительства и оснащения микроэлектронных предприятий указывают на то, что да. противодействие стран-конкурентов (в первую очередь США) в плане приобретения высоких технологий и правовые проблемы рассматриваются как факторы "против". Доля отечественных ИС на внутреннем рынке вырастет, но запланированного уровня может не достичь.

Однако не все так однозначно. При проектировании ИС и технологических процессов, управлении производственными процессами в других областях микроэлектроники все большее значение приобретает ИИ. Например, благодаря использованию ИИ в инструментальных средствах САПР можно отказаться от "ручных» операций и сократить цикл проектирования с нескольких месяцев / недель до нескольких дней и менее. Несмотря на то, что по общему уровню разработок в области ИИ КНР пока отстает от США, в плане создания и начала реализации (с учетом объемов финансирования, на чем китайцы не экономят) общенационального плана развития ИИ КНР на два года опережает США. Рано или поздно это “выстрелит», в частности, в области микроэлектроники. И тогда достижение поставленных на 2025-2030 годы целей намного реальнее.

\section{ЛИТЕРАТУРА}

1. Merritt R. China, Chips and 2019 Still Unclear // EE Times. 01.25.19. https://www.eetimes.com/

document.asp?doc_id=1334240

2. Lung Chu. Integration with global ecosystem key to growth of China's semiconductor industry // Solid State Technology. Wafer News. May 15. 2018.

http://electroiq.com/blog/2018/05/integrationwith-global-ecosystem-key-to-growth-of-chinassemiconductor-industry/

3. McGrath D. China Said to be Raising $\$ 47$ Billion Semiconductor Fund // EE Times. 5.8.2018. https://www.eetimes.com/document.asp?doc_ id $=1333268$

4. China IC Production Forecast to Show a Strong $15 \%$ 2018-2023 CAGR // IC Insights Research Bulletin. 2019. February 07. https://mail.google.com/mail/u/0/ ?tab=wm\#inbox/FMfcgxwBVWRWvBkBzXggwSrQKRgmbvCW

5. Fab spending poised for remarkable fourth year of growth // SEMI. 12.03.2018. http://www.semi.org/en/fab-spendingpoised-remarkable-fourth-year-growth

6. McGrath D. China's IC Production Forecast to Double Over Next 5 Years // EE Times. 02.08.19.

https://www.eetimes.com/document.asp?doc_ id $=1334300$

7. China's Semiconductor Fab Capacity to Reach 20 Percent Worldwide Share in 2020, Region's Equipment Market Expected to Rise to Top // SEMI. 2018. September 4. http://www.semi.org/en/chinas-semiconductor-fabcapacity-reach-20-percent-worldwide-share-2020-regionsequipment-market

8. Merritt R. China Foundry Seeks Shared Model (Guangzhou joins the provincial race for fabs) // EE Times.1.29.2018. https://www.eetimes.com/document.asp?doc_ id $=1332901$

9. Ashwin Kaja, Yan Luo. Covington Artificial Intelligence Update: China's Vision for The Next Generation of Al // Inside Privacy. 2018. March 24.

https://www.insideprivacy.com/artificial-intelligence/ chinas-vision-for-the-next-generation-of-ai/

10. Triolo P., Kania E., Webster G. Translation: Chinese government outlines Al ambitions through 2020 // New America. 2018. Jan. 26.

https://www.newamerica.org/cybersecurity-initiative/ digichina/blog/translation-chinese-government-outlinesai-ambitions-through-2020/

11. 国务院关于印发. 新一代人工智能发展规划的通知.

国发 (2017) 35号

http://www.gov.cn/zhengce/content/2017-07/20/

content_5211996.htm

12. McGrath D. Trump Creates U. S. Al Initiative // EE Times. 02.12.19 https://www.eetimes.com/document.asp?doc_ id $=1334316$ 